Tropical Journal of Pharmaceutical Research November 2015; 14 (11): 1991-1998

ISSN: $1596-5996$ (print); 1596-9827 (electronic)

(C) Pharmacotherapy Group, Faculty of Pharmacy, University of Benin, Benin City, 300001 Nigeria.

All rights reserved.

Available online at http://www.tjpr.org

Original Research Article

http://dx.doi.org/10.4314/tjpr.v14i11.6

\title{
Interactions between Plant Extracts and Cell Viability Indicators during Cytotoxicity Testing: Implications for Ethnopharmacological Studies
}

\author{
Sze Mun Chan ${ }^{1}$, Kong Soo Khoo ${ }^{2}$ and Nam Weng Sit ${ }^{1 \star}$ \\ ${ }_{1}^{1}$ Department of Biomedical Science, ${ }^{2}$ Department of Chemical Science, Faculty of Science, Universiti Tunku Abdul Rahman, \\ Bandar Barat, 31900 Kampar, Perak, Malaysia
}

*For correspondence: Email: sitnw@utar.edu.my; Tel: (605) 4688888 Ext. 1016; Fax: (605) 4661676

Received: 26 September 2014

Revised accepted: 27 August 2015

\begin{abstract}
Purpose: To compare the cytotoxicity of six medicinal plants (Acmella ciliata, Amaranthus tricolor, Coriandrum sativum, Glebionis coronaria, Kyllinga brevifolia and Tradescantia zebrina) using 3-(4, 5dimethylthiazol-2-yl)-2,5-diphenyltetrazolium bromide (MTT) and neutral red uptake (NRU) assays.

Methods: Hexane, chloroform, ethyl acetate, ethanol, methanol and water extracts were obtained for each plant by sequential solvent extraction. Cytotoxicity was evaluated in triplicate, from 640 to $5 \mu \mathrm{g} / \mathrm{mL}$, two-fold, serially on monkey kidney epithelial (Vero) cells.

Results: The hexane, chloroform and ethyl acetate extracts of the six plants were more toxic to the Vero cells compared to the ethanol, methanol and water extracts. Thirty one percent (11/36) and $75 \%$ $(27 / 36)$ of the extracts showed significant cytotoxicity $(p<0.05)$ in MTT and NRU assays, respectively. The 78, 52 and $7 \%$ cytotoxicity levels detected in 27 extracts using the MTT assay were significantly ( $p$ $<0.05)$ underestimated at 640,320 and $160 \mu \mathrm{g} / \mathrm{mL}$, respectively, using NRU assay. Nine extracts from five plants exhibited significantly lower $(p<0.05) 50 \%$ cytotoxic concentration $\left(C_{50}\right)$ when NRU assay was employed compared to MTT assay. At $640 \mu \mathrm{g} / \mathrm{mL}, 10$ of the 21 extracts were also found to react chemically with MTT, causing a 2.0 - 29.1-fold increase in the absorbance value $(550 \mathrm{~nm})$ compared to control.

Conclusion: The plant extracts of A. ciliata, A. tricolor, C. sativum, G. coronaria, K. brevifolia and T. zebrina show concentration- and extraction method-dependent cytotoxicity using MTT and NRU assays. NRU assay appears to be more sensitive and reliable than MTT assay for cell viability evaluation of the plant extracts.
\end{abstract}

Keywords: Acmella ciliata, Amaranthus tricolor, Coriandrum sativum, Glebionis coronaria, Kyllinga brevifolia and Tradescantia zebrina, Extraction, Medicinal plant, Neutral red uptake assay, Vero cell

Tropical Journal of Pharmaceutical Research is indexed by Science Citation Index (SciSearch), Scopus, International Pharmaceutical Abstract, Chemical Abstracts, Embase, Index Copernicus, EBSCO, African Index Medicus, JournalSeek, Journal Citation Reports/Science Edition, Directory of Open Access Journals (DOAJ), African Journal Online, Bioline International, Open-J-Gate and Pharmacy Abstracts

\section{INTRODUCTION}

Medicinal plants are prominent natural sources of phytochemicals, some of which have therapeutic values. A screening program was initiated by our research group whereby local natural resources, including medicinal plants for antiviral property against arboviruses such as chikungunya and dengue viruses, were tested. Cytotoxicity testing using cell lines such as African green monkey kidney epithelial (Vero) cell line is an integral part of such screening programs. The testing has been greatly aided by the use of colorimetric indicators to assess for cell viability. In this regard, 3-(4, 5-dimethylthiazol-2-yl)-2,5diphenyltetrazolium bromide (MTT) assay uses a 
water-soluble yellow tetrazolium salt (MTT), which is reduced to an insoluble purple formazan by viable cells. The absorbance of dissolved formazan, quantified spectrophotometrically, correlates with the number of intact viable cells [1]. Another technique, the neutral red uptake (NRU) assay, is based on the ability of viable cells to incorporate and concentrate the supravital dye neutral red in the lysosomes. Quantification of the dye extracted from the cells has also been shown to correlate with cell numbers [2]. Both assays have been widely used for assessment of cytotoxicity, cell viability, and proliferation studies in cell biology [3, 4].

The presence of multiple components in a plant extract has increased the complexity of a screening assay involving cell culture technique. This demands a reliable indicator for the assessment of cell viability. This study was thus conducted to determine the cytotoxic effect of the extracts from six medicinal plants against Vero cells and to compare the reliability of MTT and NRU assays.

\section{EXPERIMENTAL}

\section{Collection of plants}

Six medicinal plants were obtained from local markets and farms during October 11, 2009 to July 11,2010 . These were the whole plants of Amaranthus tricolor L. (Amaranthaceae; red amaranth), Coriandrum sativum L. (Apiaceae; coriander), Tradescantia zebrina Bosse (Commelinaceae; "Wandering Jew"), aerial part of Kyllinga brevifolia Rottb. (Cyperaceae; green kyllinga), leaves of Acmella ciliata (Kunth) Cass. (Compositae; paracress) and Glebionis coronaria (L.) Cass. ex Spach (Compositae; garland chrysanthemum). These plants were collected for our antiviral screening program. The identity of Acmella ciliata was confirmed by Dr. Kuo-Fang Chung from School of Forestry and Resource Conservation, National Taiwan University, Taiwan while the other plants were identified by Professor Hean-Chooi Ong of the Faculty of Science, University of Malaya, Malaysia. The scientific name of each plant was also crosschecked using 'The Plant List' (www.theplantlist.org). Voucher specimens of the plant samples (UTAR/FSC/08/001 for $A$. ciliata; UTAR/FSC/10/009 for $A$. tricolor, UTAR/FSC/ 10/012 for C. sativum; UTAR/FSC/10/010 for $G$. coronaria; UTAR/FSC/10/007 for $K$. brevifolia; UTAR/FSC/10/008 for T. zebrina) were prepared and deposited at the Faculty of Science, Universiti Tunku Abdul Rahman (Perak campus) herbarium.

\section{Preparation of plant extracts}

After lyophilization, the plant samples were blended into smaller pieces using a blender (Waring Commercial, Torrington, CT, USA) and subjected to sequential solvent extraction using hexane, chloroform, ethyl acetate, ethanol, methanol and water accordingly at room temperature and with agitation at $100 \mathrm{rpm}$ using an orbital shaker (TS-525D, Yihder Technology, New Taipei City, Taiwan). All solvents were of analytical grade. The filtrates were concentrated to dryness at $40{ }^{\circ} \mathrm{C}$ using a rotary evaporator (Laborota 4000, Heidolph Instruments, Schwa bach, Germany) to obtain the crude extracts while water extracts were lyophilized (Cool safe 55, Scanvac, Lynge, Denmark). Resultant dried extracts were reconstituted in dimethyl sulfoxideethanol mixture $(60: 40, \mathrm{v} / \mathrm{v})$ to achieve a stock concentration of $256 \mathrm{mg} / \mathrm{mL}$, and the stock solutions were sterilized by using $0.45 \mu \mathrm{m}$ syringe filter and stored at $-20^{\circ} \mathrm{C}$ prior to use.

\section{Cell culture}

The African green monkey kidney (Vero) cell line (CL6809) was a gift from Professor Shamala Devi (Faculty of Medicine, University of Malaya, Malaysia). The cells were cultured in Dulbecco's Modified Eagle Medium (DMEM) (Sigma-Aldrich, St. Louis, MO, USA) supplemented with $10 \%$ fetal bovine serum (FBS), 10,000 units penicillin and $10 \mathrm{mg}$ streptomycin/mL (Sigma-Aldrich, St. Louis, MO, USA), and $3.7 \mathrm{~g} / \mathrm{L}$ sodium bicarbonate at $\mathrm{pH}$ 7.4. Cells were maintained at $37^{\circ} \mathrm{C}$ under a humidified $5 \% \mathrm{CO}_{2}$ atmosphere. Passage number of $97-100$ was maintained for bioassay.

\section{MTT assay}

A confluent Vero cell monolayer with the cell density of $4 \times 10^{4}$ cells/well was seeded in 96well plates. After incubation at $37^{\circ} \mathrm{C}$ in a $5 \%$ $\mathrm{CO}_{2}$ incubator for $24 \mathrm{~h}, 100 \mu \mathrm{L}$ of each two-fold serially diluted extract (concentrations ranging from 640 to $5 \mu \mathrm{g} / \mathrm{mL}$ ) in maintenance medium (DMEM with $1 \%$ FBS) was added to the wells. Medium control (blank medium) and cell control (cells without extract treatment) were also incorporated in the same plates. The plates were incubated for another $72 \mathrm{~h}$ at $37^{\circ} \mathrm{C}$ in a $5 \% \mathrm{CO}_{2}$ incubator and the cell viability was evaluated using the MTT colorimetric assay as described by Mosmann [1] with some modifications. A 20 $\mu \mathrm{L}$ of MTT solution $(5 \mathrm{mg} / \mathrm{mL}$ in phosphate buffered saline (PBS)) was pipetted into each well followed by a 3-hour incubation period at 37 ${ }^{\circ} \mathrm{C}$ in the $5 \% \mathrm{CO}_{2}$ incubator. Seventy percent of the mixture was then removed and $150 \mu \mathrm{L}$ of 
dimethyl sulfoxide was added to the wells to dissolve the MTT formazan. The absorbance was determined at $550 \mathrm{~nm}$ using a microplate reader (Infinite M200, Tecan Austria $\mathrm{GmbH}$, Grodig, Austria). Results were obtained from three independent experiments and duplicate assays were performed for each experiment.

\section{Neutral red uptake (NRU) assay}

The assay was carried out using a modification of the method described by Repetto et al [5]. Eight concentrations $(640$ to $5 \mu \mathrm{g} / \mathrm{mL}, 100 \mu \mathrm{L}$ each) of the plant extracts, obtained by two-fold serial dilution in maintenance medium, was added into 96 -well plates containing $4 \times 10^{4}$ Vero cells/well. The cells were then incubated for $72 \mathrm{~h}$ at $37{ }^{\circ} \mathrm{C}$ with $5 \% \mathrm{CO}_{2}$. After incubation, the medium was removed from each well after which each well was washed with $150 \mu \mathrm{L}$ of PBS once, followed by the addition of $100 \mu \mathrm{L}$ of neutral red solution (40 $\mu \mathrm{g} / \mathrm{mL}$ in maintenance medium) into the well. The plates were further incubated for 2 $\mathrm{h}$ to promote dye uptake by lysosomes. Subsequently, the mixture was removed and the incorporated neutral red dye was extracted by adding $150 \mu \mathrm{L}$ of neutral red destain solution (ethanol: glacial acetic acid: water, 50:1:49, v/v/v) into each well. The absorbance value was read at $540 \mathrm{~nm}$ using a microplate reader (Infinite M200, Tecan Austria GmbH, Grodig, Austria). Medium and cell controls were also included. The results were obtained from three independent experiments. Duplicate assays were performed.

\section{Interaction test}

Selected plant extracts were prepared in the maintenance medium at a concentration of 640 $\mu \mathrm{g} / \mathrm{mL}$ and $100 \mu \mathrm{L}$ of the extracts were pipetted into empty flat bottom 96-well plates. A blank maintenance medium was included as a control. The plates were then incubated for $72 \mathrm{~h}$ at $37^{\circ} \mathrm{C}$ with $5 \% \mathrm{CO}_{2}$. After incubation, MTT solution (20 $\mu \mathrm{L}$ ) was added into the wells and the plates were incubated for $3 \mathrm{~h}$ at $37{ }^{\circ} \mathrm{C}$ with $5 \% \mathrm{CO}_{2}$. This was followed by removal of $70 \%$ mixture from the wells and addition of $150 \mu \mathrm{L}$ of DMSO into each well. The absorbance was recorded at 550 $\mathrm{nm}$. The same experiment was repeated with $\mathrm{NRU}$ assay. Neutral red solution $(100 \mu \mathrm{L})$ was added to each well and incubated for $2 \mathrm{~h}$ prior to the absorbance at $540 \mathrm{~nm}$ being measured. Since there was no cell seeding involved, washing with PBS and addition of neutral red destain solution steps were not performed. The results were obtained from three independent experiments with duplicate assays being performed for each experiment.

\section{Data analysis}

The cell viability for both assays was calculated as $[(x-y) /(z-y)] \times 100 \%$, where $x, y$, and $z$ were average absorbance of cells treated with extract, average absorbance of blank medium, and average absorbance of cell control, respectively. Fifty percent cytotoxic concentrations $\left(\mathrm{CC}_{50}\right)$ of the extracts were determined from the plots of cell viability against concentration. The data were analyzed with independent t-test (or MannWhitney $U$ test) and analysis of variance (ANOVA) using Statistical Package for the Social Sciences (SPSS) software (version 15.0 for Windows, SPSS Inc., Illinois, USA). Significance level was set at $p<0.05$.

\section{RESULTS}

Since the plant extracts for this study were obtained through sequential extraction method, the extracts were categorized as non-polar extracts (hexane and chloroform extracts), intermediate polar extract (ethyl acetate extract) and polar extracts (ethanol, methanol and water extracts). For the MTT assay, $31 \%$ of the plant extracts showed significant toxicity $(p<0.05)$ towards the Vero cells mainly at the concentration $\geq 320 \mu \mathrm{g} / \mathrm{mL}$ (Figure 1). Comparison of the extract concentrations between $320 \mu \mathrm{g} / \mathrm{mL}$ and $640 \mu \mathrm{g} / \mathrm{mL}$ revealed that the hexane and chloroform extracts of $A$. ciliata, hexane extract of $C$. sativum and hexane extract of $G$. coronaria were found to be equally toxic to the Vero cells $(p<0.05)$. In fact, the hexane extracts of $A$. ciliata, $C$. sativum, and $G$. coronaria caused more than $90 \%$ cell death at these concentrations. In contrast, polar extracts from the six medicinal plants did not exhibit any cytotoxic effect on Vero cells, except for the ethanol extract of $A$. ciliata at $640 \mu \mathrm{g} / \mathrm{mL}$, with a cell viability of $14.57 \%$. None of the extracts of K. brevifolia showed cytotoxic effect on the Vero cells.

The NRU assay revealed that $75 \%$ of the plant extracts, including the extracts of $K$. brevifolia showed significant cytotoxicity $(p<0.05)$ on the Vero cells. The cytotoxicity was even detected at much lower concentrations $(160 \mu \mathrm{g} / \mathrm{mL}$ and 80 $\mu \mathrm{g} / \mathrm{mL}$ for the chloroform extract of $C$. sativum and $160 \mu \mathrm{g} / \mathrm{mL}$ for the ethyl acetate extract of $T$. zebrina) with their cell viability of $77.59 \%, 83.12$ $\%$ and $61.94 \%$, respectively (Figure 2 ). 

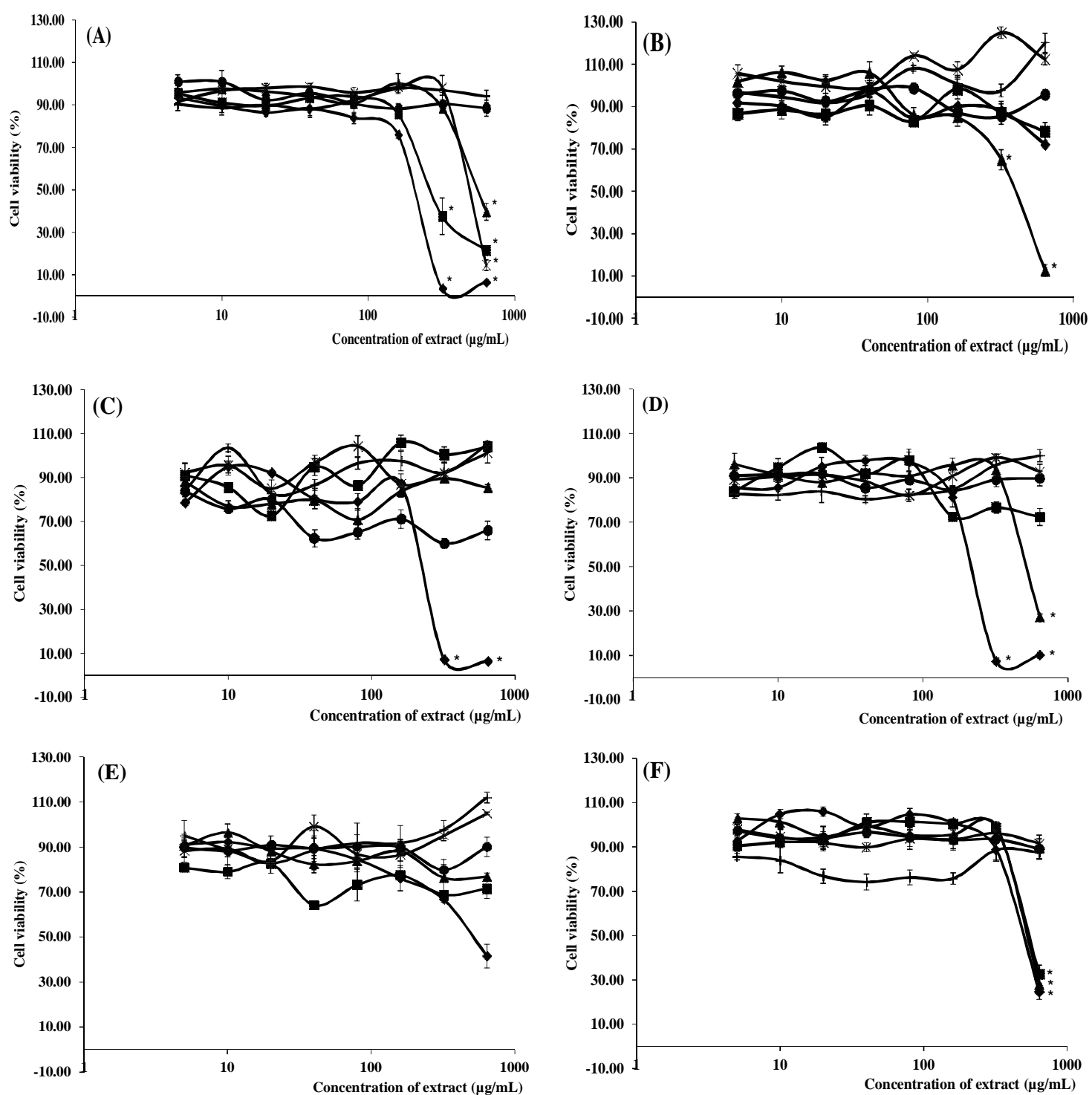

Figure 1: Effect of 36 extracts of six medicinal plants on the viability of Vero cells based on MTT assay. The results represent mean $\pm \mathrm{SEM}, n=3$. The asterisk mark indicates significant difference $(p<0.05)$ when analyzed with ANOVA test. (A) - Acmella ciliata; (B) - Amaranthus tricolor; (C) - Coriandrum sativum; (D) - Glebionis coronaria; (E) - Kyllinga brevifolia; (F) - Tradescantia zebrina. (•) - Hexane extract; (ם) - Chloroform extract; $(\boldsymbol{\Delta})$ - Ethyl acetate extract; $(\times)$ - Ethanol extract; $(+)$ - Methanol extract; $(\bullet)$ - Water extract

The NRU assay also showed that the non-polar and intermediate polar extracts from the six medicinal plants were more toxic to the Vero cells than the polar extracts, with the lowest cell viability $(0.31 \%)$ observed for the ethyl acetate extract $(640 \mu \mathrm{g} / \mathrm{mL})$ of $T$. zebrina.

Pairwise comparison of the Vero cell viability treated with these 27 extracts indicated that 78 $\%, 50 \%$ and $7 \%$ of these were resulting from significant underestimation $(p<0.05)$ of their cytotoxicity at 640,320 , and $160 \mu \mathrm{g} / \mathrm{mL}$, respectively when MTT assay was used. At the highest concentration of $640 \mu \mathrm{g} / \mathrm{mL}$, the cell viabilities obtained using NRU assay for two third of these 27 extracts were at least $50 \%$ lower than that of MTT assay. Such an underestimation was further illustrated by the $50 \%$ cytotoxic concentrations $\left(\mathrm{CC}_{50}\right)$ of the plant extracts (Table 1). Of the 12 comparisons between MTT and NRU assays where the $C_{50}$ could be determined for the extracts, 10 extracts from five medicinal plants exhibited significant cytotoxicity $(p<0.05)$. The $\mathrm{CC}_{50}$ of the hexane extract of $G$. coronaria was slightly higher ( $6 \%$ ) using NRU assay compared to MTT assay. However, the $\mathrm{CC}_{50}$ of the other nine extracts obtained using NRU assay were much lower compared to MTT assay with percentages of difference ranging from $19.6 \%$ to $56.8 \%$ (Table 1 ).

Since the results from pairwise comparison of the extracts between MTT and NRU assays indicated that 21 extracts $(78 \%)$ were 

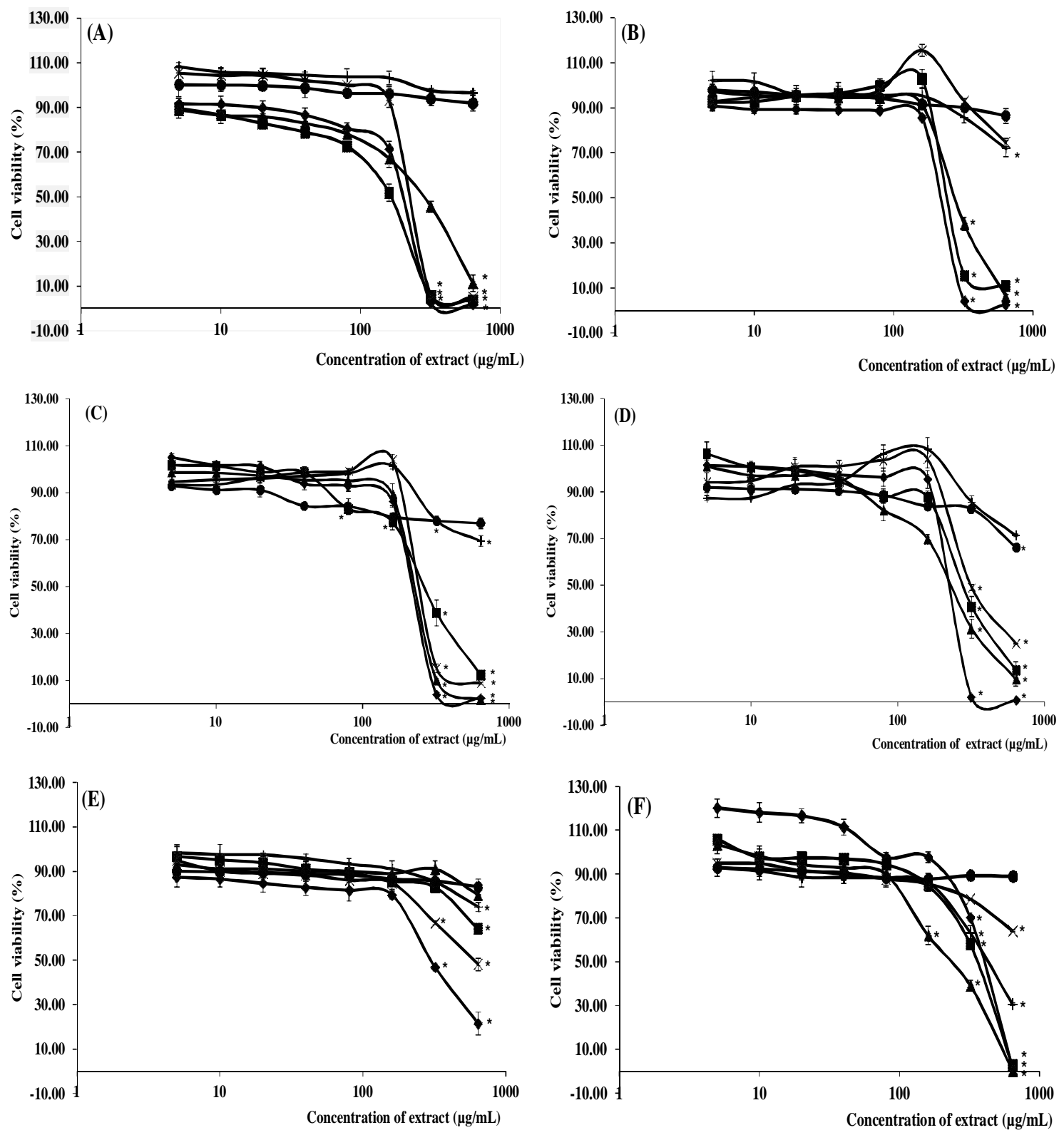

Figure 2: Effect of 36 extracts of six medicinal plants on the viability of Vero cells based on NRU assay. The results represent mean $\pm \mathrm{SEM}, n=3$. The asterisk mark indicates significant difference $(p<0.05)$ when analyzed with ANOVA test. (A) - Acmella ciliata; (B) - Amaranthus tricolor; (C) - Coriandrum sativum; (D) - Glebionis coronaria; (E) - Kyllinga brevifolia; (F) - Tradescantia zebrina. (•) - Hexane extract; ( $\square)$ - Chloroform extract; $(\mathbf{\Delta})$ - Ethyl acetate extract; $(\times)$ - Ethanol extract; $(+)$ - Methanol extract; $(\bullet)$ - Water extract

significantly underestimated at $640 \mu \mathrm{g} / \mathrm{mL}$, further spectrophotometric evaluation was carried out to detect any interaction present between the plant extracts and the indicators used in both assays. It was found that 10 of the extracts (Table 2 ) reacted chemically with MTT and caused 2.0 - 29.1 fold increase in the absorbance value at $550 \mathrm{~nm}$ compared to the control. In contrast, the increase in the absorbance (at the wavelength used, $540 \mathrm{~nm}$ ) due to chemical interaction between the plant extracts and the neutral red indicator was only $1.2-3.5$ fold. However, unlike the results from the MTT assay, this increase was not significant as the medium in the wells was removed before introduction of the neutral red solution in the NRU assay.

\section{DISCUSSION}

The assessment of cytotoxicity of six plant extracts using MTT assay resulted in some false negative results unlike the NRU assay. The MTT assay also underestimated the cytotoxicity of plant extracts at lower concentrations such as 80 
Table 1: Cytotoxic concentrations $\left(\mathrm{CC}_{50}\right)$ of extracts from six medicinal plants on Vero cells assessed using NRU and MTT assays

\begin{tabular}{|c|c|c|c|c|}
\hline \multirow{2}{*}{ Plants } & \multirow{2}{*}{ Extracts } & \multicolumn{3}{|c|}{$\mathrm{CC}_{50}(\mu \mathrm{g} / \mathrm{mL})^{\mathrm{a}}$} \\
\hline & & NRU & MTT & Difference (\%) \\
\hline \multirow[t]{4}{*}{ Acmella ciliata } & Hexane & $202.00 \pm 4.16$ & $206.33 \pm 1.86$ & -2.10 \\
\hline & Chloroform & $165.67 \pm 13.37^{\mathrm{c}}$ & $277.67 \pm 32.43$ & -40.34 \\
\hline & Ethyl acetate & $280.00 \pm 15.72^{c}$ & $581.00 \pm 19.52$ & -51.81 \\
\hline & Ethanol & $223.00 \pm 1.73^{\mathrm{C}}$ & $510.33 \pm 8.76$ & -56.30 \\
\hline \multirow{3}{*}{$\begin{array}{l}\text { Amaranthus } \\
\text { tricolor }\end{array}$} & Hexane & $217.33 \pm 0.88$ & $n a^{b}$ & $n a^{\mathrm{b}}$ \\
\hline & Chloroform & $237.00 \pm 3.00$ & $\mathrm{na}^{\mathrm{b}}$ & $n a^{b}$ \\
\hline & Ethyl acetate & $276.33 \pm 8.76^{c}$ & $410.00 \pm 29.30$ & -32.60 \\
\hline \multirow[t]{4}{*}{ Coriandrum sativum } & Hexane & $215.33 \pm 2.60$ & $220.33 \pm 4.98$ & -2.27 \\
\hline & Chloroform & $260.67 \pm 13.64$ & $n a^{\mathrm{b}}$ & $\mathrm{na}^{\mathrm{b}}$ \\
\hline & Ethyl acetate & $223.33 \pm 3.53$ & $n a^{b}$ & $n a^{b}$ \\
\hline & Ethanol & $239.00 \pm 1.00$ & $n a^{b}$ & $n a^{b}$ \\
\hline \multirow[t]{4}{*}{ Glebionis coronaria } & Hexane & $225.67 \pm 1.86^{\mathrm{C}}$ & $213.00 \pm 4.04$ & 5.95 \\
\hline & Chloroform & $280.00 \pm 16.07$ & $n a^{\mathrm{b}}$ & $\mathrm{na}^{\mathrm{b}}$ \\
\hline & Ethyl acetate & $229.67 \pm 10.27^{\mathrm{C}}$ & $531.67 \pm 9.28$ & -56.80 \\
\hline & Ethanol & $316.67 \pm 3.76$ & $n a^{b}$ & $n a^{b}$ \\
\hline Kyllinga brevifolia & Hexane & $253.00 \pm 3.00^{a}$ & $545.00 \pm 40.10$ & -53.58 \\
\hline \multirow[t]{4}{*}{ Tradescantia zebrina } & Hexane & $415.00 \pm 2.00^{C}$ & $516.00 \pm 16.07$ & -19.57 \\
\hline & Chloroform & $364.33 \pm 6.49^{\mathrm{C}}$ & $561.67 \pm 13.69$ & -35.13 \\
\hline & Ethyl acetate & $217.00 \pm 14.05^{\mathrm{C}}$ & $548.33 \pm 11.67$ & -60.43 \\
\hline & Methanol & $426.67 \pm 16.41$ & $\mathrm{na}^{\mathrm{b}}$ & $\mathrm{na}^{\mathrm{b}}$ \\
\hline
\end{tabular}

Table 2: Absorbance values for plant extracts that react chemically with the assay indicators

\begin{tabular}{|c|c|c|c|c|c|}
\hline \multirow[b]{2}{*}{ Plant } & \multirow[b]{2}{*}{$\begin{array}{c}\text { Extract } \\
(640 \mu \mathrm{g} / \mathrm{mL})\end{array}$} & \multicolumn{2}{|c|}{ MTT Assay } & \multicolumn{2}{|c|}{ NRU Assay } \\
\hline & & $\begin{array}{c}\text { Absorbance at } \\
550 \mathrm{~nm}^{\mathrm{a}}\end{array}$ & $\begin{array}{c}\text { Folds } \\
\text { (Compared } \\
\text { to control) }\end{array}$ & $\begin{array}{c}\text { Absorbance at } \\
540 \mathrm{~nm}^{a}\end{array}$ & $\begin{array}{c}\text { Folds } \\
\text { (Compared } \\
\text { to control) }\end{array}$ \\
\hline \multirow[t]{2}{*}{ Acmella ciliata } & Chloroform & $0.232 \pm 0.029$ & 2.8 & $2.258 \pm 0.066$ & 3.5 \\
\hline & Ethyl acetate & $0.208 \pm 0.029$ & 2.5 & $1.809 \pm 0.068$ & 2.8 \\
\hline $\begin{array}{l}\text { Coriandrum } \\
\text { sativum }\end{array}$ & Chloroform & $0.257 \pm 0.070$ & 3.1 & $1.834 \pm 0.112$ & 2.8 \\
\hline Glebionis & Chloroform & $0.260 \pm 0036$ & 3.1 & $1.806 \pm 0.131$ & 2.8 \\
\hline coronaria & Ethyl acetate & $0.168 \pm 0.041$ & 2.0 & $1.147 \pm 0.119$ & 1.8 \\
\hline \multirow[t]{2}{*}{ Kyllinga brevifolia } & Ethanol & $2.448 \pm 0.479$ & 29.1 & $1.079 \pm 0.039$ & 1.7 \\
\hline & Methanol & $1.562 \pm 0.096$ & 18.6 & $1.090 \pm 0.023$ & 1.7 \\
\hline \multirow{3}{*}{$\begin{array}{l}\text { Tradescantia } \\
\text { zebrina }\end{array}$} & Hexane & $0.225 \pm 0.010$ & 2.7 & $0.921 \pm 0.299$ & 1.4 \\
\hline & Chloroform & $0.206 \pm 0.040$ & 2.4 & $0.948 \pm 0.062$ & 1.5 \\
\hline & Ethyl acetate & $0.204 \pm 0.081$ & 2.4 & $0.806 \pm 0.053$ & 1.2 \\
\hline
\end{tabular}

${ }^{a}$ The results represent mean \pm standard deviation, $n=3$

and $160 \mu \mathrm{g} / \mathrm{mL}$. Based on both assays, it is known that 27 extracts from the six medicinal plants had significant toxicity on Vero cells using $\mathrm{NRU}$ assay as compared to 11 extracts from five medicinal plants using MTT assay. This difference occurred in $A$. tricolor (hexane, chloroform and ethanol extracts), C. sativum (chloroform, ethyl acetate, ethanol and methanol extracts), G. coronaria (chloroform, ethanol and water extracts), K. brevifolia (hexane, chloroform, ethanol and methanol extracts) and $T$. zebrina (ethanol and methanol extracts). These results 
suggest that the NRU assay is more sensitive and reliable than the MTT assay. This is of importance because such a deviation may lead to errors in determining the selectivity index of an extract as the index depends on the $\mathrm{CC}_{50}$ of the extract.

The MTT assay is based on the reduction of MTT into formazan crystals by living cells. The intracellular reducing power is mainly provided by $\mathrm{NAD}(\mathrm{P}) \mathrm{H}$ which is derived from dehydrogenase activity in mitochondria, endoplasmic reticulum and plasma membrane $[6,7]$. One of the possible causes of false negative results could be chemical interactions between the extracts and the MTT indicator. This may be caused by the presence of some reducing agents in the plant extracts. Although nicotinamde coenzymes appear as the principal factor for MTT reduction, other reducing agents cannot be excluded, ascorbic acid and compounds with free thiol groups being the most relevant $[8,9]$. Some natural products such as kaempferol and resveratrol are found to have the ability to enhance the MTT-reducing activity directly $[8,10]$. It has been reported that in $\mathrm{pH}$-buffered media lacking cells, MTT is reduced spontaneously to formazan by amitraz (an acaricide), the absorbance being proportional to both MTT concentration and incubation time [11]. The MTT assay was also been reported to be significantly influenced by a number of parameters such as respiratory chain inhibitors of mitochondria [12], medium $\mathrm{pH}$ [13], the D-glucose concentration in the growth medium and the cellular concentration of pyridine nucleotides [14], and the efflux proteins [15], which might be one of the factors that leads to the inaccurate estimation of the viable cells.

Unlike the MTT assay, the possibility of plant extracts to react chemically with the indicator in $\mathrm{NRU}$ assay is eliminated as the protocol for this assay involves the washing step whereby the treated Vero cells were washed with PBS before adding the neutral red solution. Thus, the compounds that could have contributed to the chemical reaction were removed although neutral red reacted chemically with the plant extracts in the interaction test (Table 2). The inherent property of the protocol of NRU assay makes this assay more reliable than the MTT assay. The $\mathrm{NRU}$ assay is sensitive and readily quantifiable as the neutral red dye does not accumulate in the lysosomes of dead or damaged cells [5]. In fact, the first application of the NRU assay to the assessment of natural toxins with different types of human cell lines were found to be more sensitive than MTT assay [16].

\section{CONCLUSION}

NRU assay is more sensitive in determining cytotoxicity in plant extracts than MTT assay. The chemical interaction between MTT and plant extracts appears to interfere with the reliability of MTT assay. As the study regarding the interaction between MTT and plant extracts has not been extensively documented, further work should be carried out to determine the types of phytochemicals responsible for the chemical interaction.

\section{ACKNOWLEDGEMENT}

The authors thank Kuok Foundation Berhad for supporting this study via a research grant (vote no. $4393 / 000)$.

\section{REFERENCES}

1. Mosmann T. Rapid colorimetric assay for cellular growth and survival: application to proliferation and cytotoxicity assays. J Immunol Methods 1983; 65(12): 55-63.

2. Borenfreund E, Puerner JA. Toxicity determined in vitro by morphological alterations and neutral red absorption. Toxicol Lett 1985; 24(2-3): 119-124.

3. Berridge MV, Herst PM, Tan AS. Tetrazolium dyes as tools in cell biology: new insights into their cellular reduction. Biotechnol Annu Rev 2005; 11: 127-152.

4. Van Meerloo J, Kaspers GJL, Cloos J. Cell sensitivity assays: the MTT assay. Methods Mol Biol 2011; 731: 237-245.

5. Repetto G, del Peso A, Zurita JL. Neutral red uptake assay for the estimation of cell viability/cytotoxicity. Nat Protoc 2008; 3: 1125-1131.

6. Bernas T, Dobrucki JW. The role of plasma membrane in bioreduction of two tetrazolium salts, MTT, and CTC. Arch Biochem Biophys 2000; 380: 108-116.

7. Stockert JC, Blázquez-Castro A, Cañete M, Horobin RW, Villanueva A. MTT assay for cell viability: Intracellular localization of the formazan product is in lipid droplets. Acta Histochem 2012; 114(8): 785-796.

8. Bruggisser $R$, von Daeniken $K$, Jundt $G$, Schaffner $W$, Tullberg-Reinert $H$. Interference of plant extracts, phytoestrogens and antioxidants with the MTT tetrazolium assay. Planta Med 2002; 68: 445-448.

9. Shoemaker M, Cohen I, Campbell M. Reduction of MTT by aqueous herbal extracts in the absence of cells. $J$ Ethnopharmacol 2004; 93(2-3): 381-384.

10. Bernhard D, Schwaiger D, Crazzolara R, Tinhofer I, Kofler R, Csordas A. Enhanced MTT-reducing activity under growth inhibition by resveratrol in CEM-C7H2 lymphocytic leukemia cells. Cancer Lett 2003; 195: 193-199.

11. Young FM, Phungtamdet W, Sanderson BJS. Modification of MTT assay conditions to examine the

Trop J Pharm Res, November 2015; 14(11): 1997 
cytotoxic effects of amitraz on the human lymphoblastoid cell line WIL2NS. Toxicology In Vitro 2005; 19(8): 1051-1059.

12. Loveland BE, Johns TG, Mackay IR, Vaillant F, Wang ZX, Hertzog PJ. Validation of the MTT dye assay for enumeration of cells in proliferative and antiproliferative assays. Biochem Int 1992; 27(3): 501-510.

13. Jabbar SAB, Twentyman PR, Watson JV. The MTT assay underestimates the growth inhibitory effects of interferons. Br J Cancer 1989; 60(4): 523-528.

14. Vistica $D$, Skehan $P$, Scudiero $D$, Monks A, Pittman A, Boyd R. Tetrazolium-based assays for cellular viability: a critical examination of selected parameters affecting formazan production. Cancer Res 1991; 51(10): 2515-2520.

15. Vellonen KS, Honkakoski $P$, Urtti A. Substrates and inhibitors of efflux proteins interfere with the MTT assay in cells and may lead to underestimation of drug toxicity. Eur J Pharm Sci 2004; 23(2): 181-188.

16. Babich $H$, Borenfreund E. Cytotoxicity of $T-2$ toxin and its metabolites determined with the neutral red cell viability assay. Appl Environ Microbiol 1991; 57(7): 2101-2103. 